\title{
Anti-inflammatory effects of leaf and branch extracts of honeyberry (Lonicera caerulea) on lipopolysaccharide-stimulated RAW264.7 cells through ATF3 and Nrf2/HO-1 activation
}

\author{
MI-YUN AN ${ }^{1}$, HYUN JI EO ${ }^{2}$, HO JUN SON ${ }^{2}$, NA GYEONG GEUM ${ }^{1}$, GWANG HUN PARK ${ }^{2}$ and JIN BOO JEONG ${ }^{1}$ \\ ${ }^{1}$ Department of Medicinal Plant Resources, Andong National University, Andong, Gyeongsangbuk 36729; ${ }^{2}$ Forest Medicinal \\ Resources Research Center, National Institute of Forest Science, Yeongju, Gyeongsangbuk 36040, Republic of Korea
}

Received June 27, 2020; Accepted September 30, 2020

DOI: $10.3892 / \mathrm{mmr} .2020 .11638$

\begin{abstract}
Honeyberry (Lonicera caerulea) has long been used as a traditional medicine in China, Japan and northern Russia. Functional studies of honeyberry have mainly focused on the fruits, which have been reported to exert various pharmacological activities, including anti-inflammatory activity, with limited or no studies on the other parts of the plant, such as the leaves and branches. In the present study, the anti-inflammatory effects of extracts of the leaves (HBL), branches (HBB) and fruit (HBF) of honeyberry plant were evaluated in lipopolysaccharide (LPS)-stimulated RAW264.7 cells. HBL and HBB significantly inhibited the production of proinflammatory mediators in LPS-stimulated RAW264.7 cells, and the inhibitory effects of $\mathrm{HBL}$ and $\mathrm{HBB}$ were stronger than those of HBF. HBL and HBB blocked the nuclear accumulation of p65 independently of I $\kappa \mathrm{B}-\alpha$. HBL did not inhibit the phosphorylation of ERK1/2 or p38; however, HBB effectively inhibited the phosphorylation of $\mathrm{p} 38$ but not ERK1/2. HBL and HBB increased the expression of heme oxygenase-1 (HO-1) protein by inducing the nuclear accumulation of nuclear factor erythroid 2-related factor 2 (Nrf2) through the activation of the reactive oxygen species (ROS)/p38 pathway; the reduction
\end{abstract}

Correspondence to: Professor Jin Boo Jeong, Department of Medicinal Plant Resources, Andong National University, 1375 Gyeongdong, Andong, Gyeongsangbuk 36729, Republic of Korea

E-mail: jjb0403@anu.ac.kr

Abbreviations: ATF3, activating transcription factor-3; COX-2, cyclooxygenase-2; DCFH-DA, 2',7'-dichlorofluorescein diacetate; HO-1, heme oxygenase-1; HBB, honeyberry branch extract; HBF, honeyberry fruit extract; HBL, honeyberry leaf extract; iNOS, inducible nitric oxide synthase; IL-1 $\beta$, interleukin-1 $\beta$; IL-6, interleukin-6; LPS, lipopolysaccharide; MAPK, mitogen-activated protein kinase; MTT, 3-(4,5-dimethylthiazol-2-yl)-2,5-diphenyltetrazolium bromide; NF- $\kappa \mathrm{B}$, nuclear factor- $\mathrm{kB}$; NO, nitric oxide; Nrf2, nuclear factor erythroid 2-related factor 2

Key words: anti-inflammation, honeyberry, inflammatory response, Lonicera caerulea, macrophage in inducible nitric oxide synthase (iNOS) and interleukin-1 $\beta$ (IL-1 $\beta$ ) expression by HBL and HBB was inhibited by HO-1 knockdown. In addition, HBL and HBB increased the expression of activating transcription factor-3 (ATF3), and the reduction in iNOS and IL-1 $\beta$ expression by $\mathrm{HBL}$ and $\mathrm{HBB}$ was inhibited by ATF3 knockdown. Collectively, HBL and HBB inhibited LPS-induced nuclear factor- $\kappa \mathrm{B}$ activation by blocking the nuclear accumulation of p65, increasing HO-1 expression through activation of the ROS/p38/Nrf2 pathway, and increasing ATF3 expression. Furthermore, HBB inhibited LPS-induced $\mathrm{p} 38$ phosphorylation. These findings suggest that HBL and HBB may have great potential as natural products for the development of anti-inflammatory drugs.

\section{Introduction}

Inflammation, which is one of the physical barriers of innate immunity, is the protective response by which the body eliminates harmful stimuli, such as damaged cells, pathogens and irritants (1). However, the prolonged inflammatory response of immune cells to noxious stimuli leads to chronic inflammation, which causes various diseases, including rheumatoid arthritis, type 2 diabetes, cancer, cirrhosis, Alzheimer's disease and neurological diseases (2). Macrophages, which play a pivotal role in the innate immune system, release various inflammatory cytokines and mediators to protect the body from external harmful factors (3). However, excessive amounts of inflammatory cytokines, such as tumor necrosis factor (TNF)- $\alpha$, interleukin (IL)-1 $\beta$ and IL-6, and inflammatory mediators, such as nitric oxide (NO), prostaglandin $\mathrm{E}_{2}$, inducible $\mathrm{NO}$ synthase (iNOS) and cyclooxygenase-2 (COX-2), have been linked to pathophysiological events and chronic inflammatory diseases (4). Therefore, the control of excessive inflammatory responses is important for the prevention of chronic inflammatory diseases, and drugs that suppress excessive inflammatory responses are constantly being developed.

Currently used anti-inflammatory drugs, such as non-steroidal anti-inflammatory drugs (NSAIDs), may cause serious side effects. Therefore, numerous researchers have focused on the development of anti-inflammatory drugs from plant sources that are considered to be safe, effective, biocompatible and cost-effective alternatives (2). Berries 
are fruits rich in nutritive compounds, such as minerals, vitamins and dietary fiber. They also contain polyphenolic compounds that have strong anti-inflammatory properties (5). Honeyberry (Lonicera caerulea) has long been used as a traditional medicine in China, Japan and northern Russia (6). Honeyberry fruits have been reported to have strong antioxidant effects due to their ascorbic acid content and the presence of phenolic compounds, including anthocyanins, flavonoids and low-molecular-weight phenolic acids (7). In addition, a study found that honeyberry fruits had the strongest antioxidant property among 12 types of colored berries from northern China (8). A number of studies have shown the various effects of honeyberry fruits, which include antiinflammatory $(9,10)$, hepatoprotective (11), lipid and glucose metabolism-enhancing (12), anti-hyperthyroidism (13), anti-obesity (14) and anticancer effects $(15,16)$. These fruits contain a variety of polyphenolic compounds, including protocatechuic acid, caffeic acid, chlorogenic acid, coumaric acid and ferulic acid, which have a close association with anti-inflammatory effects $(17,18)$. In addition, the anti-inflammatory activity of honeyberry cultivars has been shown to depend on the levels of polyphenolic compounds they contain (19). Much research has been carried out into the pharmacological activity of honeyberry; however, these studies have mainly focused on honeyberry fruits, and reports of the pharmacological activities of its leaves and branches are limited. The leaves and branches of plants are important for the development of natural medicines due to the presence of high levels of functional substances with various biological activities; therefore, pharmacological studies on the leaves and branches of honeyberry are recommended. Notably, the leaves of chokeberry and mulberry have higher contents of functional substances and higher levels of antioxidant activity than the fruits $(20,21)$. Thus, in the present study, the anti-inflammatory activity of honeyberry leaves and branches was evaluated, and their mechanisms of action were investigated.

\section{Materials and methods}

Chemical reagents. 3-(4,5-Dimethylthiazol-2-yl)-2,5diphenyltetrazolium bromide (MTT), N-acetyl-L-cysteine (NAC), SB203580 (p38 inhibitor), lipopolysaccharide (LPS) and $2^{\prime}, 7^{\prime}$-dichlorofluorescein diacetate (DCFH-DA) were purchased from Sigma-Aldrich (Merck KGaA). The control, HO-1 (cat. no. sc-35555) and ATF3 (cat. no. sc-29758) small interfering RNAs (siRNAs) were purchased from Santa Cruz Biotechnology, Inc.

Sample preparation. Honeyberry (FMCLC-20190506-01) was provided by Forest Medicinal Resources Research Center, Korea. The leaves, branches or fruits of honeyberry were extracted according to a previously described method (22). Briefly, leaves, branches or fruits of honeyberry (20 g) were extracted by shaking in $70 \%$ ethanol $(400 \mathrm{ml})$ at room temperature for $72 \mathrm{~h}$. The ethanol-soluble fraction was then filtered, concentrated to a volume of $\sim 120 \mathrm{ml}$ using a vacuum evaporator and freeze-dried. The ethanol extracts were kept in a freezer $\left(-80^{\circ} \mathrm{C}\right)$ until use. The extracts from the leaves (HBL), branches (HBB) or fruits (HBF) of honeyberry were dissolved in dimethyl sulfoxide (DMSO) when used to treat cells. DMSO was used as a control and the final DMSO concentration in the cell culture was $\leq 0.1 \%(\mathrm{v} / \mathrm{v})$.

Determination of total phenolic content. Total phenolic content was measured using the Folin-Ciocalteu assay (23). Briefly, $0.5 \mathrm{ml} \mathrm{HBL}$, HBB or HBF $(50 \mathrm{mg} / \mathrm{ml})$ was mixed with $0.5 \mathrm{ml} 2 \mathrm{~N}$ Folin-Ciocalteu reagent (cat. no. 47641; Sigma-Aldrich; Merck KGaA) at room temperature for $5 \mathrm{~min}$, followed by the addition of $2 \mathrm{ml} 7 \%$ sodium carbonate $(\mathrm{w} / \mathrm{v})$. The mixtures were incubated for $90 \mathrm{~min}$ at room temperature. The absorbance of the mixture was then measured at $750 \mathrm{~nm}$ using a UV/visible spectrophotometer (Xma-3000PC; Human Corporation).

Determination of total flavonoid content. Total flavonoid content was measured according to a previously described method with some modifications (23). Briefly, $20 \mu 1 \mathrm{HBL}$, HBB or HBF $(50 \mathrm{mg} / \mathrm{ml}), 80 \mu \mathrm{l}$ distilled water and $6 \mu \mathrm{l}$ $5 \% \mathrm{NaNO}_{2}$ were mixed and incubated for $5 \mathrm{~min}$ at room temperature. Next, $12 \mu \mathrm{l} 10 \% \mathrm{AlCl}_{3} \cdot 6 \mathrm{H}_{2} \mathrm{O}$ was added and the mixture was incubated at room temperature. After $6 \mathrm{~min}$, $40 \mu 11 \mathrm{M} \mathrm{NaOH}$ was added and the mixture was incubated for $11 \mathrm{~min}$ at room temperature. Finally, the absorbance was measured at $510 \mathrm{~nm}$ using a UV/visible spectrophotometer (Xma-3000PC).

Cell culture. RAW264.7 cells purchased from the American Type Culture Collection were cultured according to a previously described method (22). The cells were maintained in DMEM/F-12 1:1 (Hyclone Laboratories Inc.) containing 10\% fetal bovine serum (Gibco; Thermo Fisher Scientific, Inc.), $100 \mathrm{U} / \mathrm{ml}$ penicillin and $100 \mu \mathrm{g} / \mathrm{ml}$ streptomycin at $37^{\circ} \mathrm{C}$ under a humidified atmosphere of $5 \% \mathrm{CO}_{2}$.

Cell viability assay. MTT assay for measuring cell viability was performed according to the method described in a previous study (22). Briefly, the cells were plated on a 96-well plate at a density of $3 \times 10^{3}$ cells/well, followed by treatment with HBL and $\operatorname{HBB}(0,100$ or $200 \mu \mathrm{g} / \mathrm{ml})$ at $37^{\circ} \mathrm{C}$ for $24 \mathrm{~h}$. Next, the cells were treated with $50 \mu \mathrm{l}$ MTT solution $(1 \mathrm{mg} / \mathrm{ml})$ at $37^{\circ} \mathrm{C}$ for $4 \mathrm{~h}$. After $4 \mathrm{~h}$, the cell culture supernatant was removed and DMSO was added to dissolve the resulting crystals. The formation of formazan was evaluated by measuring the absorbance at $570 \mathrm{~nm}$ using a UV/visible spectrophotometer (Xma-3000PC).

Measurement of NO production. The Griess assay was performed to measure NO production, following a previously described method (22). Briefly, after plating RAW264.7 cells $\left(1 \times 10^{5}\right.$ cells/well) on a 12 -well plate for $24 \mathrm{~h}$, the cells were pretreated with $100 \mathrm{and} / \mathrm{or} 200 \mu \mathrm{g} / \mathrm{ml} \mathrm{HBL}, \mathrm{HBB}$ and HBF, and $100 \mu \mathrm{g} / \mathrm{ml}$ ibuprofen at $37^{\circ} \mathrm{C}$ for $4 \mathrm{~h}$ and then co-treated with LPS $(1 \mu \mathrm{g} / \mathrm{ml})$ at $37^{\circ} \mathrm{C}$ for $20 \mathrm{~h}$. Then, $100 \mu \mathrm{l}$ cell culture supernatant was mixed with $100 \mu$ l Griess reagent (Sigma-Aldrich; Merck KGaA) at room temperature for $15 \mathrm{~min}$, and the absorbance was measured at $540 \mathrm{~nm}$ using $\mathrm{UV} /$ visible spectrophotometer (Xma-3000PC).

Measurement of reactive oxygen species (ROS). The levels of ROS produced by HBL- and HBB-treated RAW264.7 cells 
were measured with DCFH-DA staining. Briefly, RAW264.7 cells plated on a 96 -well plate $\left(3 \times 10^{3}\right.$ cells/well $)$ for $24 \mathrm{~h}$ were treated with $200 \mu \mathrm{g} / \mathrm{ml} \mathrm{HBL}$ and $\mathrm{HBB}$ at $37^{\circ} \mathrm{C}$ for $24 \mathrm{~h}$. The culture medium was then removed, and the cells were treated with DCFH-DA $(10 \mu \mathrm{M})$ for $20 \mathrm{~min}$ at $37^{\circ} \mathrm{C}$ in the dark. After washing the cells three times with $1 \mathrm{X}$ phosphate-buffered saline (PBS) and the fluorescence intensity was measured at an excitation wavelength of $488 \mathrm{~nm}$ and emission wavelength of $525 \mathrm{~nm}$ using a UV/visible spectrophotometer (Xma-3000PC).

Isolation of nuclear fraction. Nuclear protein was extracted from the treated RAW264.7 cells using a Nuclear Extract kit (Active Motif, Inc.) according to the manufacturer's protocols. The nuclear protein was stored at $-80^{\circ} \mathrm{C}$ prior to further analysis.

SDS-PAGE and western blotting. Western blot analysis was performed according to a previously described method (22). RAW264.7 cells were pretreated with 100 and $200 \mu \mathrm{g} / \mathrm{ml} \mathrm{HBL}$ and $\mathrm{HBB}$ at $37^{\circ} \mathrm{C}$ for $4 \mathrm{~h}$ and then co-treated with LPS $(1 \mu \mathrm{g} / \mathrm{ml})$ at $37^{\circ} \mathrm{C}$ for $30 \mathrm{~min}$ or $1 \mathrm{~h}$. In addition, RAW264.7 cells were pretreated with SB203580 (20 $\mu \mathrm{M}$; p38 inhibitor) or NAC (10 mM; ROS scavenger) at $37^{\circ} \mathrm{C}$ for $2 \mathrm{~h}$ and then co-treated with $200 \mu \mathrm{g} / \mathrm{ml} \mathrm{HBL}$ and $\mathrm{HBB}$ at $37^{\circ} \mathrm{C}$ for $20 \mathrm{~min}$. After treatment, RAW264.7 cells were washed three times with cold 1X PBS, and the protein was extracted using radioimmunoprecipitation buffer containing $50 \mathrm{mM}$ Tris Base/Tris- $\mathrm{HCl}, 150 \mathrm{mM} \mathrm{NaCl}$, $0.5 \%$ sodium deoxycholate, $0.1 \%$ sodium dodecyl sulfate and $1 \%$ Nonidet P-40 substitute (Boston BioProducts) containing protease and phosphatase inhibitor cocktails (Sigma-Aldrich; Merck $\mathrm{KGaA}$ ) at $4^{\circ} \mathrm{C}$ for $30 \mathrm{~min}$. The protein concentration was quantified using a BCA protein assay (Thermo Fisher Scientific, Inc.). Briefly, $5 \mu \mathrm{l}$ cell lysate was mixed with $45 \mu \mathrm{l}$ distilled water and $1 \mathrm{ml}$ BCA protein assay solution (Reagent $\mathrm{A}: \mathrm{B}=50: 1, \mathrm{v} / \mathrm{v})$, and the mixture was incubated at $37^{\circ} \mathrm{C}$ for $30 \mathrm{~min}$. The absorbance was then measured at $562 \mathrm{~nm}$ using a UV/visible spectrophotometer (Xma-3000PC). The protein (30 $\mu \mathrm{g} /$ lane) was separated with $10 \%$ SDS-PAGE and transferred to a PVDF membrane (Bio-Rad Laboratories, Inc.). After blocking the PVDF membrane using 5\% non-fat dry milk in Tris-buffered saline containing $0.05 \%$ Tween-20 (TBS-T) with stirring at room temperature for $1 \mathrm{~h}$, the PVDF membrane was incubated overnight at $4^{\circ} \mathrm{C}$ with the following primary antibodies in $0.05 \%$ TBS-T containing 5\% non-fat dry milk: IкB- $\alpha$ (1:1,000; cat. no. 4814), p65 (1:1,000; cat. no. 8242), phospho-ERK1/2 (1:1,000; cat. no. 4377), ERK1/2 (1:1,000; cat. no. 9102), phospho-p38 (1:1,000; cat. no. 4511), p38 (1:1,000; cat. no. 9212), heme oxygenase 1 (HO-1; 1:1,000; cat. no. 70081), nuclear factor erythroid 2-related factor 2 (Nrf2; 1:1,000; cat. no. 12721), $\beta$-actin (1:1,000; cat. no. 5172) and TATA-box-binding protein (TBP; 1:1,000; cat. no. 8515) all from Cell Signaling Technology, Inc., and activating transcription factor-3 (ATF-3; 1:1,000; cat. no. sc-188) from Santa Cruz Biotechnology, Inc. After treatment with the primary antibodies, the PVDF membrane was washed three times with $0.05 \%$ TBS-T, and then incubated with the following secondary antibodies in $0.05 \%$ TBS-T containing $5 \%$ non-fat dry milk for $1 \mathrm{~h}$ at room temperature: Anti-rabbit immunoglobulin $\mathrm{G}(\mathrm{IgG})$, horseradish peroxidase (HRP)-linked antibody $(1: 1,000$; cat. no. 7074) and anti-mouse IgG, HRP-linked antibody
(1:1,000; cat. no. 7076), both from Cell Signaling Technology, Inc. Chemiluminescence was detected with Amersham ECL western blotting reagent (Cytiva) and visualized using a LI-COR C-DiGit Blot Scanner (Li-COR Biosciences). The density of the western blot bands was calculated using the software UN-SCAN-IT gel version 5.1 (Silk Scientific, Inc.).

Reverse transcriptase-polymerase chain reaction (RT-q)PCR. RT-PCR was performed according to a previously described method (22). After treatment, total RNA was extracted from the cells using a RNeasy Mini kit (Qiagen Sciences, Inc.), and cDNA was synthesized from total RNA (1 $\mu \mathrm{g})$ using a Verso cDNA Synthesis kit (Thermo Fisher Scientific, Inc.) according to the manufacturer's protocol. PCR was performed using a PCR Master Mix (Promega Corporation) and mouse primers for iNOS, COX-2, IL-1 $\beta$, IL-6 and GAPDH as follows: iNOS: Forward, 5'-ttgtgcatcgacctaggctggaa-3' and reverse, 5'-gacctttcgcattagcatggaagc-3'; COX-2: Forward, 5'-gtactggctcatgctggacga-3' and reverse, 5'-caccatacactgccaggtcagcaa-3'; IL-1 $\beta$ : Forward, 5'-ggcaggcagtatcactcatt-3' and reverse, 5'-cccaaggccacaggtattt-3'; IL-6: Forward, 5'-gaggataccactccaacagacc-3' and reverse, 5'-aagtgcatcatcgttgttcataca-3'; TNF- $\alpha$ : Forward, 5'-tggaactggcagaagaggca-3' and reverse, 5'-tgctcctccacttggtggtt-3'; GAPDH: Forward, 5'-ggactgtggtcatgagccttcca-3' and reverse, 5'-actcacggcaaattcaacggcac-3'. PCR reaction conditions were as follows: $5 \mathrm{~min}$ at $94^{\circ} \mathrm{C}$ for denaturation, 30 cycles of $30 \mathrm{sec}$ at $94^{\circ} \mathrm{C}$ for denaturation, $1 \mathrm{~min}$ at $55^{\circ} \mathrm{C}$ for annealing and $1 \mathrm{~min}$ at $72^{\circ} \mathrm{C}$ for elongation and final extension for $10 \mathrm{~min}$ at $72^{\circ} \mathrm{C}$. The PCR results were visualized using $1 \%$ agarose gel electrophoresis and Safe Shine Green (10,000 X; Biosesang). The density of the mRNA bands was calculated using the software UN-SCAN-IT gel version 5.1 .

siRNA transfection. RAW264.7 cells were seeded in 6-well plates $\left(1 \times 10^{5}\right.$ cells/well) and incubated at $37^{\circ} \mathrm{C}$ for $24 \mathrm{~h}$. The cells were then transfected with control, HO-1 or ATF3 siRNA at $37^{\circ} \mathrm{C}$ for $48 \mathrm{~h}$ at a concentration of $100 \mathrm{nM}$ using TransIT-TKO transfection reagent (Mirus Bio, LLC) according to the manufacturer's instructions. After 48 h, RAW264.7 cells were pretreated with $200 \mu \mathrm{g} / \mathrm{ml} \mathrm{HBL}$ and $\mathrm{HBB}$ were treated at $37^{\circ} \mathrm{C}$ for $4 \mathrm{~h}$ and then co-treated with LPS $(1 \mu \mathrm{g} / \mathrm{ml})$ at $37^{\circ} \mathrm{C}$ for $20 \mathrm{~h}$. Following treatment, mRNA expression levels of HO-1, ATF3, iNOS or IL-1 $\beta$ were analyzed using RT-qPCR.

High-performance liquid chromatography (HPLC) analysis of $H B L, H B B$ and $H B F$. An analysis of the anti-inflammatory compounds in $\mathrm{HBL}, \mathrm{HBB}$ and $\mathrm{HBF}$ was performed using a Waters 1525 HPLC system with Waters 2487 -dual $\lambda$ absorbance detector (Waters Corporation). The column was equipped with a SunFire $^{\mathrm{TM}}$ C18 column (250x4.6 mm; Waters Corporation), and the binary mobile phase consisted of water (solvent A) and acetonitrile containing $1 \%$ acetic acid (solvent $\mathrm{B}$ ). The flow rate was kept constant at $1.0 \mathrm{ml} / \mathrm{min}$ at $37^{\circ} \mathrm{C}$ for a total run time of $40 \mathrm{~min}$. The mobile phase was programmed consecutively in a linear gradient as follows: $0-5 \min (10 \% \mathrm{~A})$; $5-10 \mathrm{~min}(10 \rightarrow 15 \% \mathrm{~A}) ; 10-15 \mathrm{~min}(15 \% \mathrm{~A})$, and $15-40 \mathrm{~min}$ $(15 \rightarrow 40 \% \mathrm{~A})$. The injection volume of the extract was $10 \mu \mathrm{l}$ and the elution was monitored at $254 \mathrm{~nm}$. The anti-inflammatory compounds of HBL, HBB and HBF were identified by 
A

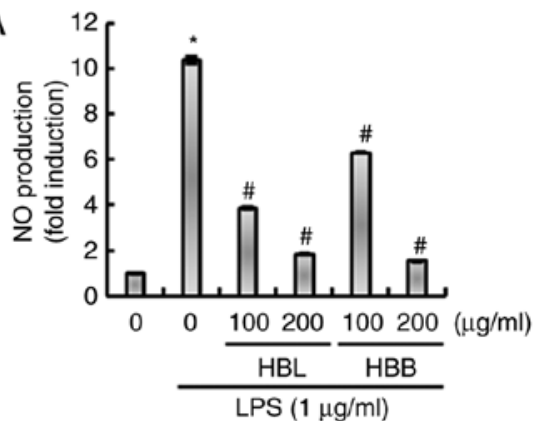

B

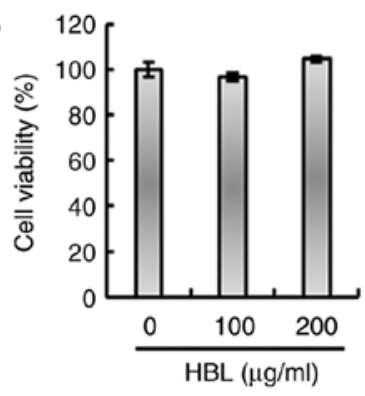

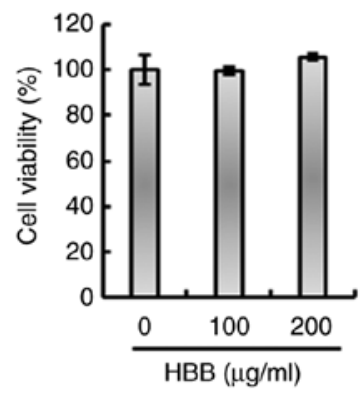

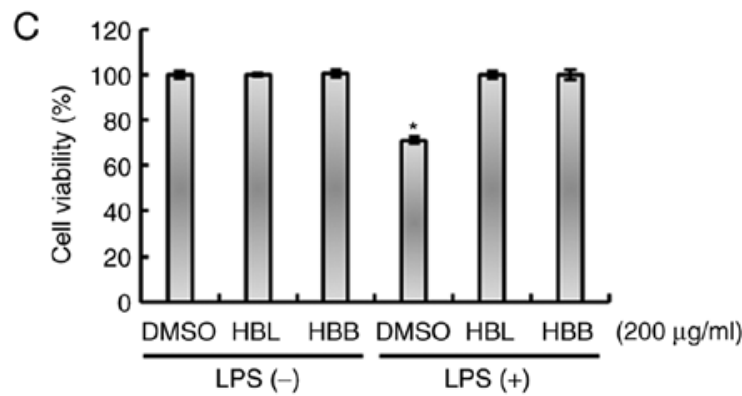

Figure 1. Effects of HBL and HBB on NO production and cell viability in LPS-stimulated RAW264.7 cells. (A) RAW264.7 cells were pretreated with 100 and $200 \mu \mathrm{g} / \mathrm{ml} \mathrm{HBL}$ and HBB for $4 \mathrm{~h}$ and then co-treated with LPS $(1 \mu \mathrm{g} / \mathrm{ml})$ for $20 \mathrm{~h}$. The concentration of NO in the cell culture medium was measured by Griess assay. (B) RAW264.7 cells were treated with 100 and $200 \mu \mathrm{g} / \mathrm{ml} \mathrm{HBL}$ and HBB for $24 \mathrm{~h}$. The cell viability was then measured using MTT assay. (C) RAW264.7 cells were treated with $200 \mu \mathrm{g} / \mathrm{ml} \mathrm{HBL}$ and HBB in the absence or presence of LPS $(1 \mu \mathrm{g} / \mathrm{ml})$ for $24 \mathrm{~h}$. The cell viability was measured using MTT assay. ${ }^{*} \mathrm{P}<0.05$ vs. the untreated cells and ${ }^{\#} \mathrm{P}<0.05$ vs. the cells treated with LPS alone. HBL, honeyberry leaf extract; HBB, honeyberry bark extract; NO, nitric oxide; LPS, lipopolysaccharide; MTT, 3-(4,5-dimethylthiazol-2-yl)-2,5-diphenyltetrazolium bromide; DMSO, dimethylsulfoxide.

comparison with the chromatograms of analytical standards, including protocatechuic acid, chlorogenic acid, caffeic acid, coumaric acid and ferulic acid.

Statistical analysis. All experiments were performed in triplicate. Data are presented as the mean \pm standard error of the mean. Data analysis was carried out using SPSS software (version 19.0; IBM Corp.). One-way analysis of variance followed by Tukey's honestly significant difference test was used to compare differences among groups. $\mathrm{P}<0.05$ was considered to indicate a significant difference.

\section{Results}

$H B L$ and $H B B$ suppress the overproduction of inflammatory cytokines and mediators in LPS-stimulated RAW264.7 cells. RAW264.7 cells were pretreated with HBL, HBB or HBF for $4 \mathrm{~h}$ to ensure that the extracts were sufficiently absorbed by the cells, and then co-treated with LPS for $20 \mathrm{~h}$ so that inflammatory mediators were expressed by LPS in sufficient quantities for detection (22). HBL and HBB significantly reduced the LPS-mediated production of NO (Fig. 1A). The results of the MTT assay demonstrated that HBL and HBB were not toxic to RAW264.7 cells (Fig. 1B), which indicates that the inhibition of NO production by HBL and HBB was not due to the cytotoxicity of the extracts. The effects of HBL and HBB on cell viability in the presence of LPS were also evaluated. As shown in Fig. 1C, treatment with LPS alone decreased cell viability, while HBL and HBB attenuated the LPS-induced reduction in cell viability. The ability of HBL and HBB to block the LPS-induced overexpression of inflammatory mediators, namely iNOS and COX-2, and inflammatory cytokines, namely IL- $1 \beta$, IL- 6 and TNF- $\alpha$, in RAW264.7 cells was also investigated. As shown in Fig. 2, the upregulation of iNOS, COX-2, IL-1 $\beta$, IL- 6 and TNF- $\alpha$ was observed in LPS-treated RAW264.7 cells, which was significantly inhibited by HBL. Similarly, HBB significantly attenuated the expression of iNOS, COX-2, IL-1 $\beta$ and IL-6, but not TNF- $\alpha$ in the LPS-induced cells. Previous studies have reported the anti-inflammatory activity of $\operatorname{HBF}(9,10)$. Therefore, the anti-inflammatory activities of HBL, HBB and $\mathrm{HBF}$ were compared in the present study. As shown in Fig. 3A and B, the inhibitory effect of HBL on the production of NO and expression of iNOS and IL-1 $\beta$ was higher than that of $\mathrm{HBB}$ at a concentration of $100 \mu \mathrm{g} / \mathrm{ml}$. Moreover, $\mathrm{HBF}$ did not significantly inhibit the LPS-induced production of NO and expression of iNOS and IL-1 $\beta$ (Fig. 3A and B). We hypothesized that the differences in the activities of the extracts may be associated with the levels of polyphenols and flavonoids they contain. Therefore, the total polyphenol and flavonoid contents of HBL, HBB and HBF were compared. As shown in Fig. 3C, the total polyphenol and flavonoid contents were reduced in the order $\mathrm{HBL}>\mathrm{HBB}>\mathrm{HBF}$, which was the same as the order of their inhibitory activities against the production of inflammatory mediators. This result indicates that the difference in the inhibitory activities of HBL, HBB and $\mathrm{HBF}$ against the production of inflammatory mediators is likely due to differences in the total polyphenol and flavonoid contents of the extracts. Furthermore, the anti-inflammatory activities of HBL and $\mathrm{HBB}$ were compared with that of ibuprofen, an NSAID. As shown in Fig. 3D, the inhibitory activity of $\mathrm{HBB}$ against $\mathrm{NO}$ production was lower than that of ibuprofen, whereas the inhibitory activity of HBL was comparable with that of ibuprofen. 

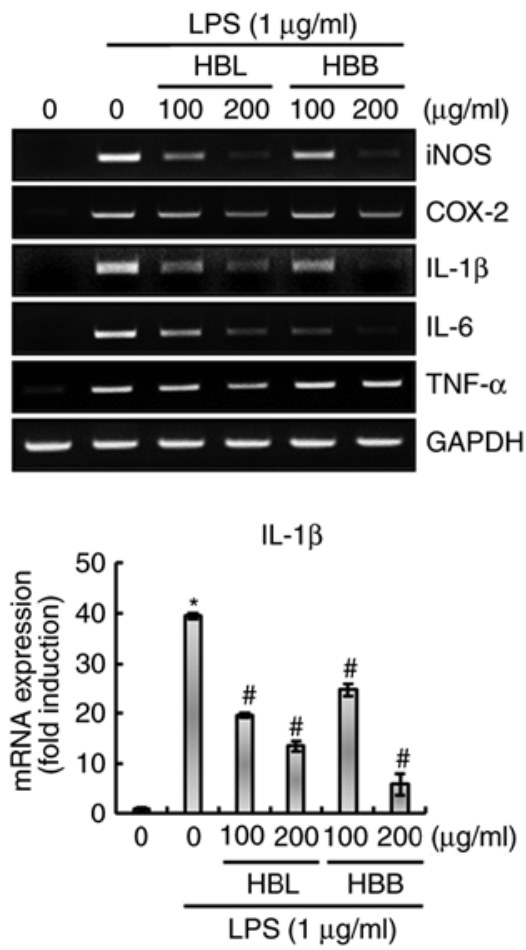
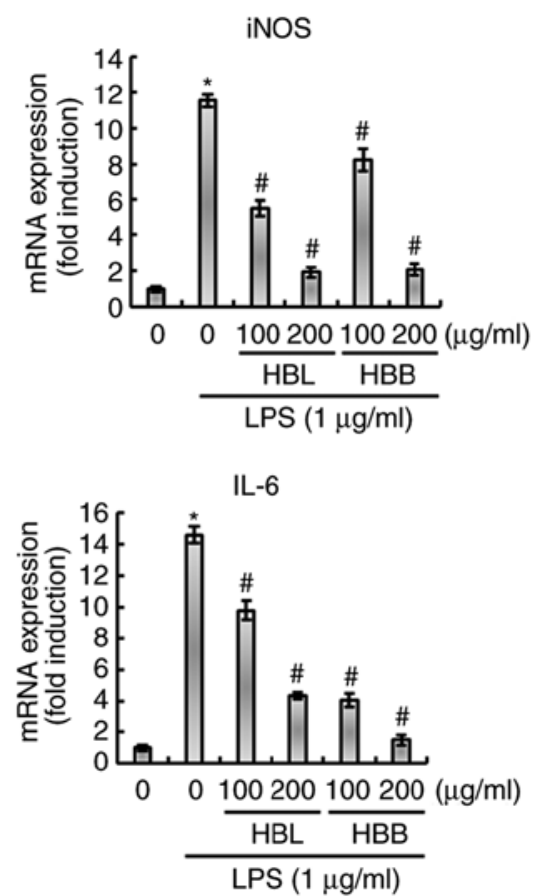
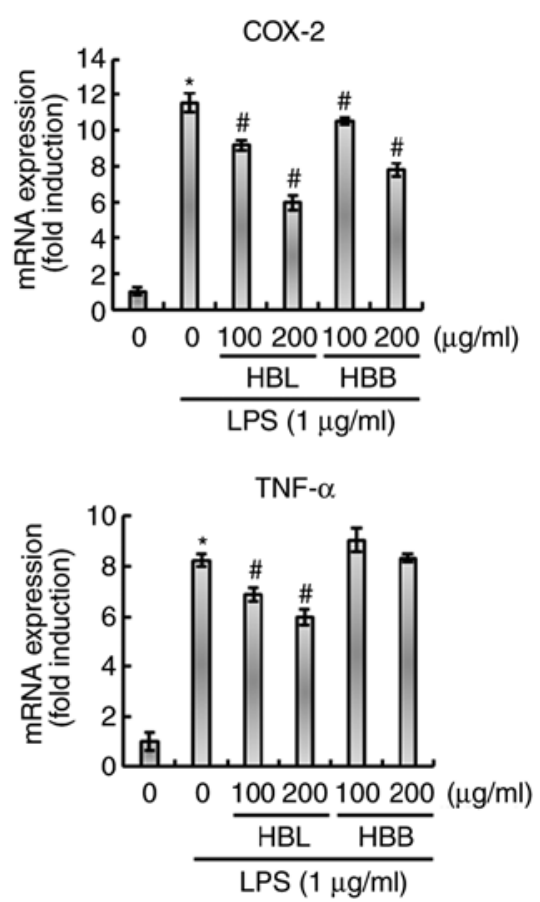

Figure 2. Effects of HBL and HBB on the expression of pro-inflammatory mediators in LPS-stimulated RAW264.7 cells. RAW264.7 cells were pretreated with 100 and $200 \mu \mathrm{g} / \mathrm{ml} \mathrm{HBL}$ and HBB for $4 \mathrm{~h}$ and then co-treated with LPS $(1 \mu \mathrm{g} / \mathrm{ml})$ for $20 \mathrm{~h}$. Total RNA was extracted after the treatment. GAPDH was used as the internal control for analysis using reverse transcription-polymerase chain reaction. " $\mathrm{P}<0.05$ vs. untreated cells and ${ }^{\#} \mathrm{P}<0.05$ vs. cells treated with LPS alone. HBL, honeyberry leaf extract; HBB, honeyberry bark extract; LPS, lipopolysaccharide; iNOS, inducible nitric oxide synthase; COX, cyclooxygenase; IL-1 $\beta$, interleukin $1 \beta$; IL-6, interleukin 6; TNF- $\alpha$, tumor necrosis factor $\alpha$.

Effects of $H B L$ and $H B B$ on the regulation of $N F-\kappa B$ and mitogen-activated protein kinase (MAPK) signaling pathways in LPS-stimulated RAW264.7 cells. The ability of HBL and HBB to inhibit the LPS-mediated activation of NF- $\kappa B$ was investigated. As shown in Fig. 4A, HBL and HBB did not suppress the LPS-induced degradation of IкB- $\alpha$; however, HBL and HBB significantly attenuated the LPS-induced nuclear accumulation of NF- $\kappa \mathrm{B}$ p65 (Fig. 4B). These results indicate that HBL and $\mathrm{HBB}$ may inhibit the activation of $\mathrm{NF}-\kappa \mathrm{B}$ signaling independently of I $\kappa \mathrm{B}-\alpha$ degradation. Whether HBL and HBB inhibit the LPS-induced activation of the MAPK signaling pathway was also investigated. As shown in Fig. 4A, LPS increased the phosphorylation levels of p38 and ERK1/2, which was not inhibited by HBL. However, HBB significantly attenuated the LPS-induced phosphorylation of p38 but not that of ERK1/2. These results indicate that HBL did not inhibit the LPS-induced activation of the MAPK signaling pathway, whereas HBB inhibited the activation of $\mathrm{p} 38$.

Effect of $H B L$ and $H B B$ on HO-1 expression in RAW264.7 cells. As shown in Fig. 5A, HBL significantly increased the expression of HO-1 protein from $1 \mathrm{~h}$ after treatment. The expression level of HO-1 was observed to be highest at $6 \mathrm{~h}$ of HBL treatment, and gradually decreased when the treatment duration was $>6 \mathrm{~h}$. HBB started to significantly increase the expression level of HO-1 protein from $6 \mathrm{~h}$ of treatment, and the level continued to increase until $24 \mathrm{~h}$ after treatment. The effect of different HBL and HBB concentrations on HO-1 protein expression levels were also examined. As the previous results confirmed that the HO-1 expression induced by $\mathrm{HBL}$ and $\mathrm{HBB}$ was highest at 6 and $10 \mathrm{~h}$ after the start of treatment, respectively, RAW264.7 cells were treated with HBL and HBB for 6 and 10 h. As shown in Fig. 5B, HBL and $\mathrm{HBB}$ concentration-dependently increased the HO-1 protein level. Furthermore, whether the increase in HO-1 protein level induced by HBL and HBB was associated with the LPS-mediated overexpression of iNOS and IL-1 $\beta$ was evaluated. The results demonstrated that the knockdown of HO-1 by transfection with HO-1 siRNA blocked the HBLand $\mathrm{HBB}$-induced downregulation of iNOS and IL-1 $\beta$ in LPS-stimulated RAW264.7 cells (Fig. 5C). These results indicate that HBL and HBB inhibited the overexpression of pro-inflammatory mediators through the upregulation of the HO-1 protein expression level.

$H B L-$ and $H B B$-induced increase in $\mathrm{HO}-1$ protein level is dependent on ROS/p38 activation. It has been reported that ROS increase the expression of HO-1 and are upstream of p38 (24). Isoegomaketone has been shown to inhibit the production of pro-inflammatory mediators through the activation of a ROS/p38/HO-1 pathway (24). Thus, the effect of ROS/p38 signaling on the HBL- and HBB-mediated expression of HO-1 was investigated. As shown in Fig. 6A, the inhibition of p38 by SB203580 and of ROS by NAC suppressed the HBL- and HBB-induced expression of HO-1. Thus, whether HBL and HBB induce the production of ROS was investigated. As shown in Fig. 6B, ROS production was observed in HBL- and HBB-treated RAW264.7 cells. In addition, HBL and HBB increased the phosphorylation level of $\mathrm{p} 38$ (Fig. 6C), and the inhibition of ROS by NAC attenuated the 

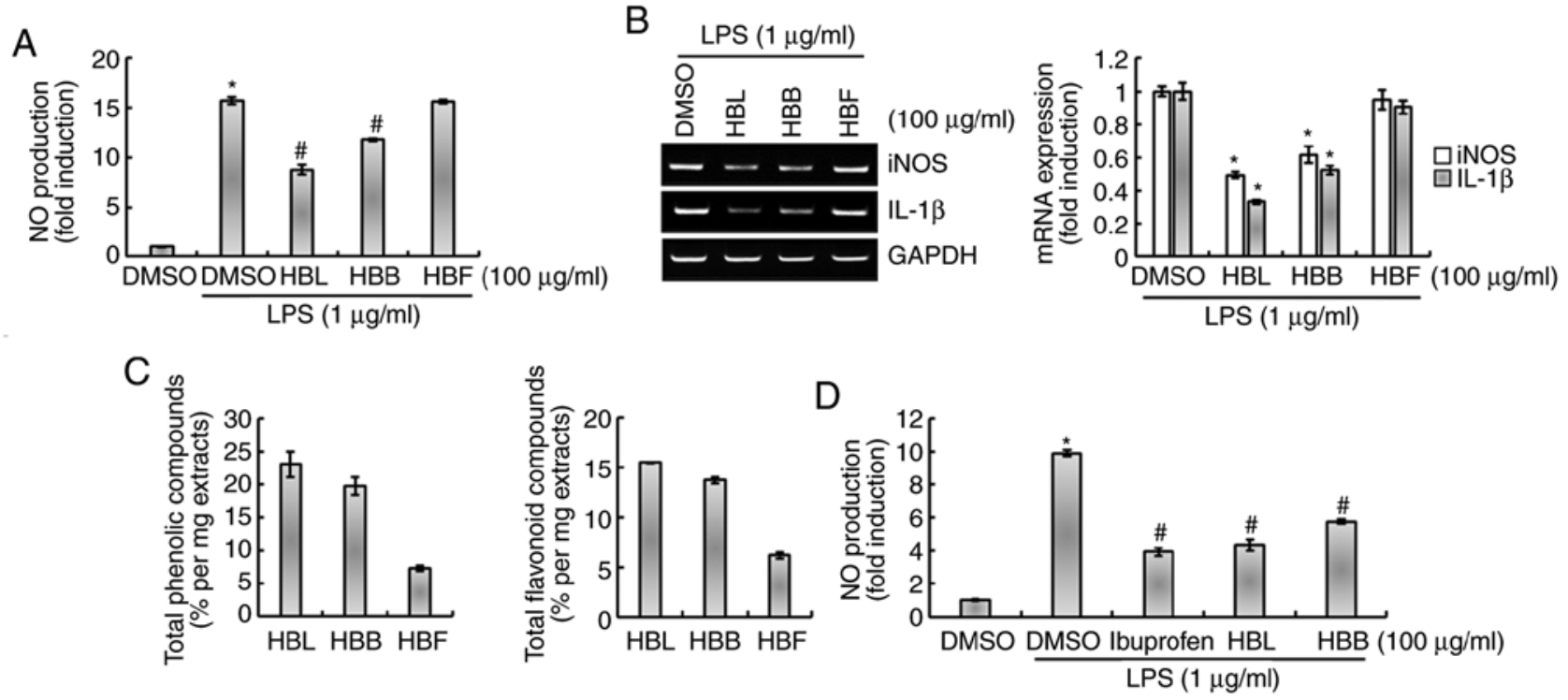

Figure 3. Comparison of the inhibitory effects of HBL, HBB and HBF on the LPS-induced production of NO, iNOS and IL-1 1 in RAW264.7 cells. (A) RAW264.7 cells were pretreated with $100 \mu \mathrm{g} / \mathrm{ml} \mathrm{HBL}, \mathrm{HBB}$ or HBF for $4 \mathrm{~h}$ and then co-treated with LPS $(1 \mu \mathrm{g} / \mathrm{ml})$ for $20 \mathrm{~h}$. The concentration of NO in the cell culture medium was measured by Griess assay. (B) Total RNA was extracted after the treatment. GAPDH was used as internal control for analysis using reverse transcription-polymerase chain reaction. ${ }^{*} \mathrm{P}<0.05$ vs. cells treated with LPS alone. (C) Contents of total phenolic and flavonoid compounds in HBL, HBB and HBF were analyzed. (D) RAW264.7 cells were pretreated with $100 \mu \mathrm{g} / \mathrm{ml}$ ibuprofen, HBL or HBB for $4 \mathrm{~h}$ and then co-treated with LPS $(1 \mu \mathrm{g} / \mathrm{ml})$ for $20 \mathrm{~h}$. The concentration of NO in the cell culture medium was measured by Griess assay. ${ }^{*} \mathrm{P}<0.05$ vs. untreated cells and ${ }^{\#} \mathrm{P}<0.05$ vs. cells treated with LPS alone. HBL, honeyberry leaf extract; HBB, honeyberry bark extract; HBF, honeyberry flower extract; LPS, lipopolysaccharide; NO, nitric oxide; iNOS, inducible NO synthase; IL-1 $\beta$, interleukin $1 \beta$; DMSO, dimethylsulfoxide.
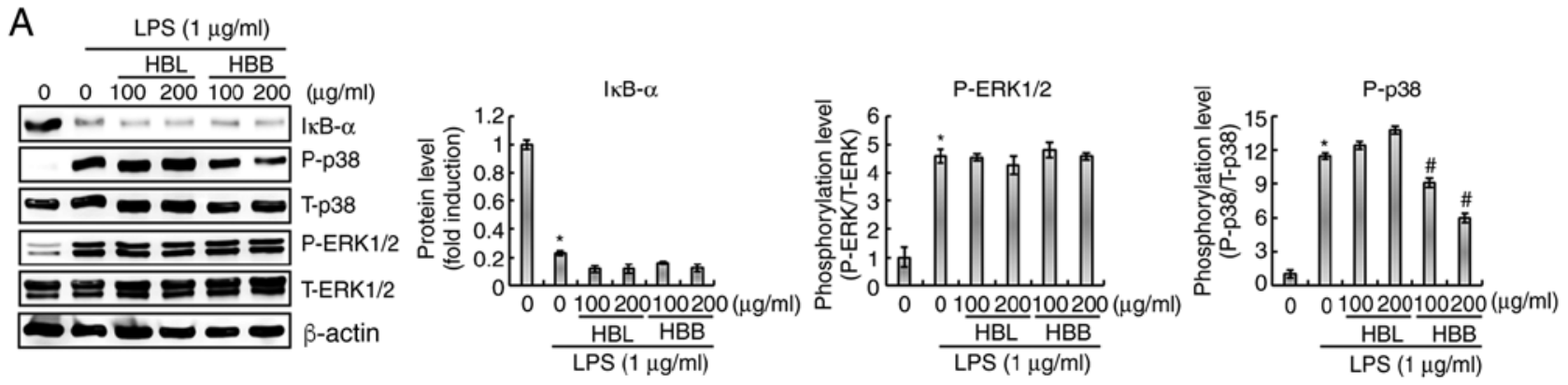

B
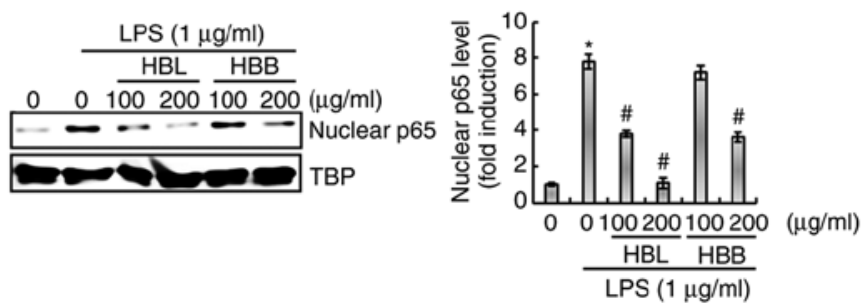

Figure 4. Inhibitory effects of HBL and HBB on NF- $\mathrm{kB}$ and MAPK activation in LPS-stimulated RAW264.7 cells. (A) RAW264.7 cells were pretreated with 100 and $200 \mu \mathrm{g} / \mathrm{ml} \mathrm{HBL}$ and HBB for $4 \mathrm{~h}$ and then co-treated with LPS $(1 \mu \mathrm{g} / \mathrm{ml})$ for $30 \mathrm{~min}$. (B) RAW264.7 cells were pretreated with $100 \mathrm{and} 200 \mu \mathrm{g} / \mathrm{ml} \mathrm{HBL}$ and HBB and then co-treated with LPS $(1 \mu \mathrm{g} / \mathrm{ml})$ for $1 \mathrm{~h}$. After the treatment, nuclear protein was prepared. The cell lysates were subjected to sodium dodecyl sulfate-polyacrylamide gel electrophoresis and western blotting was performed using antibodies against IкB- $\alpha, \mathrm{P}-\mathrm{p} 38$, p38, P-ERK1/2, ERK1/2 and p65. Actin or TBP was used as the internal control for western blot analysis. ${ }^{*} \mathrm{P}<0.05$ vs. untreated cells and ${ }^{*} \mathrm{P}<0.05$ vs. cells treated with LPS alone. HBL, honeyberry leaf extract; HBB, honeyberry bark extract; NF- $\mathrm{BB}$, nuclear factor- $\mathrm{\kappa B}$; MAPK, mitogen-activated protein kinase; LPS, lipopolysaccharide; P, phosphorylated; T, total; TBP, TATA-box-binding protein.

HBL and HBB-induced p38 phosphorylation (Fig. 6D). These results indicate that HBL and $\mathrm{HBB}$ induced $\mathrm{HO}-1$ expression through the ROS-dependent activation of $\mathrm{p} 38$.

$H B L$ - and $H B B$-induced increase in $H O-1$ protein level is dependent on ROS/p38/Nrf2 activation. The nuclear accumulation of Nrf2 is associated with the upregulation of HO-1 expression $(22,24)$. Therefore, whether HBL and HBB influence the nuclear accumulation of $\mathrm{Nrf} 2$ was investigated. As shown in Fig. 7A, the nuclear accumulation of Nrf2 significantly increased after $1 \mathrm{~h}$ of HBL and HBB treatment. In addition, HBL and HBB induced a concentration-dependent 
A

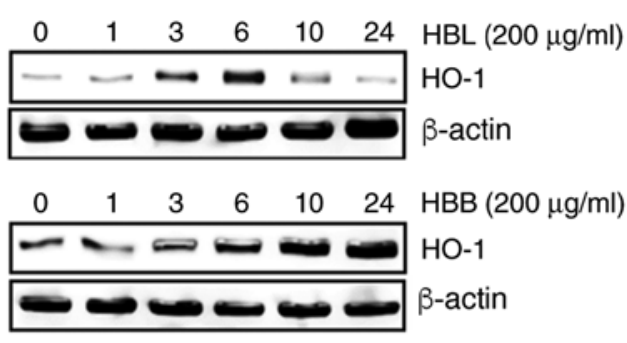

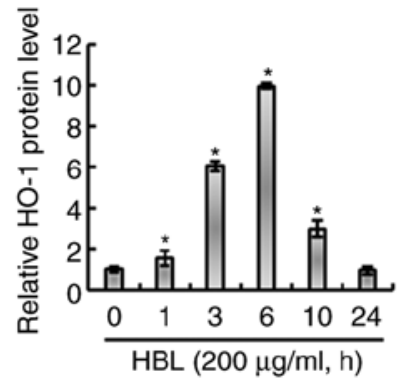

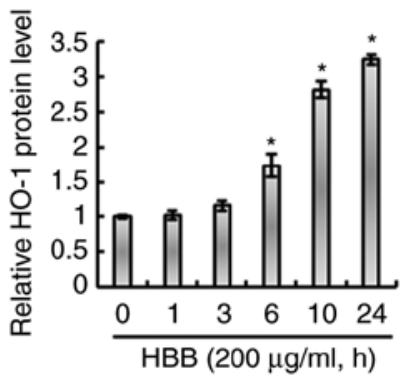

B

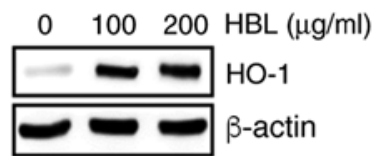

$0 \quad 100200 \mathrm{HBB}(\mu \mathrm{g} / \mathrm{ml})$

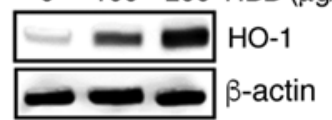

C

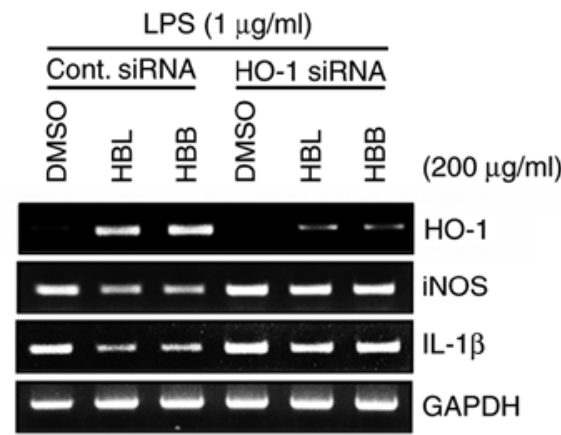

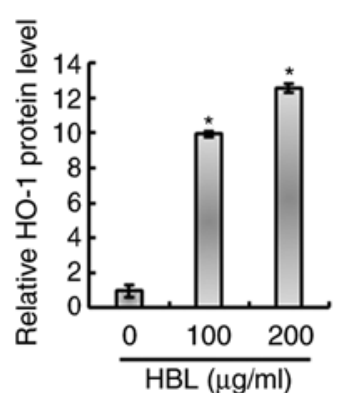
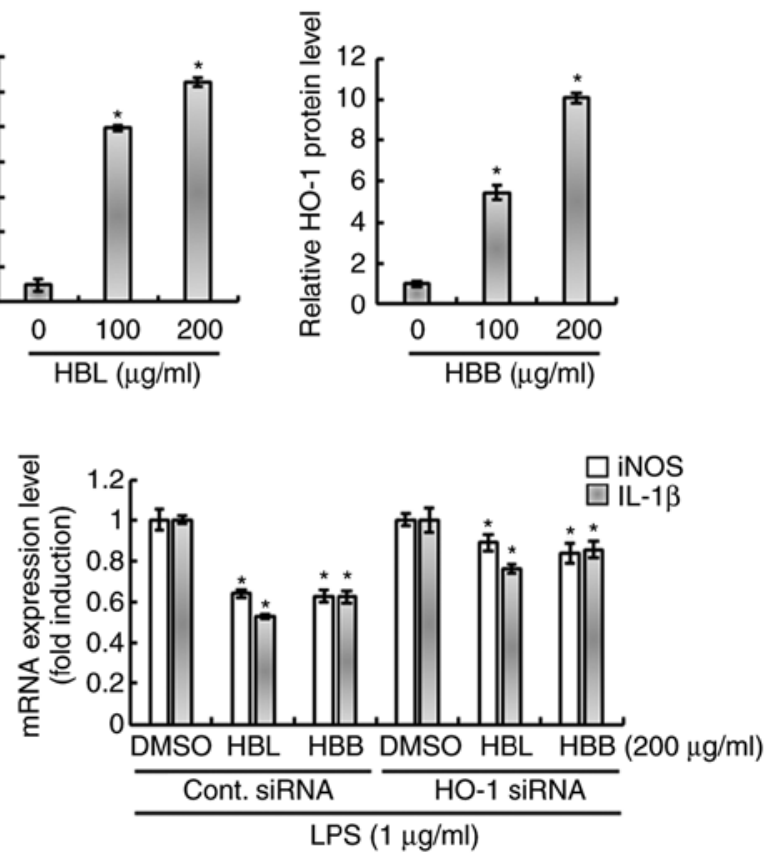

Figure 5. Effects of HBL and HBB on HO-1 expression in RAW264.7 cells. (A) RAW264.7 cells were treated with $200 \mu \mathrm{g} / \mathrm{ml} \mathrm{HBL}$ and $\mathrm{HBB}$ for the indicated times. (B) RAW264.7 cells were treated with HBL (100 and $200 \mu \mathrm{g} / \mathrm{ml})$ for $6 \mathrm{~h}$ or HBB (100 and $200 \mu \mathrm{g} / \mathrm{ml})$ for $10 \mathrm{~h}$. The cell lysates were subjected to and western blotting was performed using an antibody against HO-1. Actin was used as an internal control for western blot analysis. (C) RAW264.7 cells were transfected with control or HO-1 siRNA for $48 \mathrm{~h}$. After the transfection, the cells were pretreated with $200 \mu \mathrm{g} / \mathrm{ml} \mathrm{HBL}$ and $\mathrm{HBB}$ for $4 \mathrm{~h}$ and then co-treated with LPS $(1 \mu \mathrm{g} / \mathrm{ml})$ for $20 \mathrm{~h}$. After the treatment, total RNA was prepared. * $\mathrm{P}<0.05$ vs. cells without HBL or HBB treatment. HBL, honeyberry leaf extract; HBB, honeyberry bark extract; HO-1, heme oxygenase 1; siRNA, small interfering RNA.

increase in the nuclear accumulation of $\mathrm{Nrf2}$ (Fig. 7B). Furthermore, it was observed that the inhibition of p38 by SB203580 and the inhibition of ROS by NAC blocked the nuclear accumulation of Nrf2 induced by HBL and HBB (Fig. 7C). These results indicate that HBL and HBB induced the upregulation of HO-1 protein through the activation of ROS, p38 and Nrf2.

Upregulation of ATF3 contributes to the inhibition of the production of pro-inflammatory mediators by $H B L$ and $H B B$. There is evidence to suggest that ATF3 inhibits the inflammatory response (25). Thus, the effect of ATF3 on the inhibition of pro-inflammatory mediators by HBL and HBB was investigated. As shown in Fig. 8A, HBL and HBB rapidly increased the expression of ATF3. In addition, HBL and HBB dose-dependently increased the ATF3 protein expression level (Fig. 8B). The knockdown of ATF3 by transfection with ATF3 siRNA was observed to attenuate the HBL- and HBB-induced downregulation of iNOS and IL-1 $\beta$ (Fig. 8C). These results indicate that the upregulation of ATF3 by HBL and HBB may be associated with the downregulation of pro-inflammatory mediators.

Analysis of bioactive compounds in $H B L, H B B$ and $H B F$. Standardization of materials is essential for the development of functional products. Thus, the levels of certain polyphenolic compounds in HBL, HBB and HBF were analyzed, as honeyberry has been reported to contain polyphenolic compounds such as protocatechuic acid, caffeic acid, chlorogenic acid, coumaric acid and ferulic acid $(17,18)$. As shown in Fig. 9, chlorogenic acid (58.66 $\mu \mathrm{g} / \mathrm{g}$ extract), caffeic acid $(21.51 \mu \mathrm{g} / \mathrm{g}$ extract), coumaric acid (120.51 $\mu \mathrm{g} / \mathrm{g}$ extract) and ferulic acid (283.31 $\mu \mathrm{g} / \mathrm{g}$ extracts) were detected in HBL. In HBB, protocatechuic acid (4.23 $\mu \mathrm{g} / \mathrm{g}$ extract), chlorogenic acid (21.86 $\mu \mathrm{g} / \mathrm{g}$ extract), caffeic acid (43.88 $\mu \mathrm{g} / \mathrm{g}$ extract), coumaric acid $(26.77 \mu \mathrm{g} / \mathrm{g}$ extract) and ferulic acid (8.69 $\mu \mathrm{g} / \mathrm{g}$ extract) were detected. HBF contained protocatechuic acid $(6.53 \mu \mathrm{g} / \mathrm{g}$ extract), chlorogenic acid (27.23 $\mu \mathrm{g} / \mathrm{g}$ extract), coumaric acid (5.44 $\mu \mathrm{g} / \mathrm{g}$ extract) and ferulic acid (7.99 $\mu \mathrm{g} / \mathrm{g}$ extract). The anti-inflammatory activities of these polyphenolic compounds 

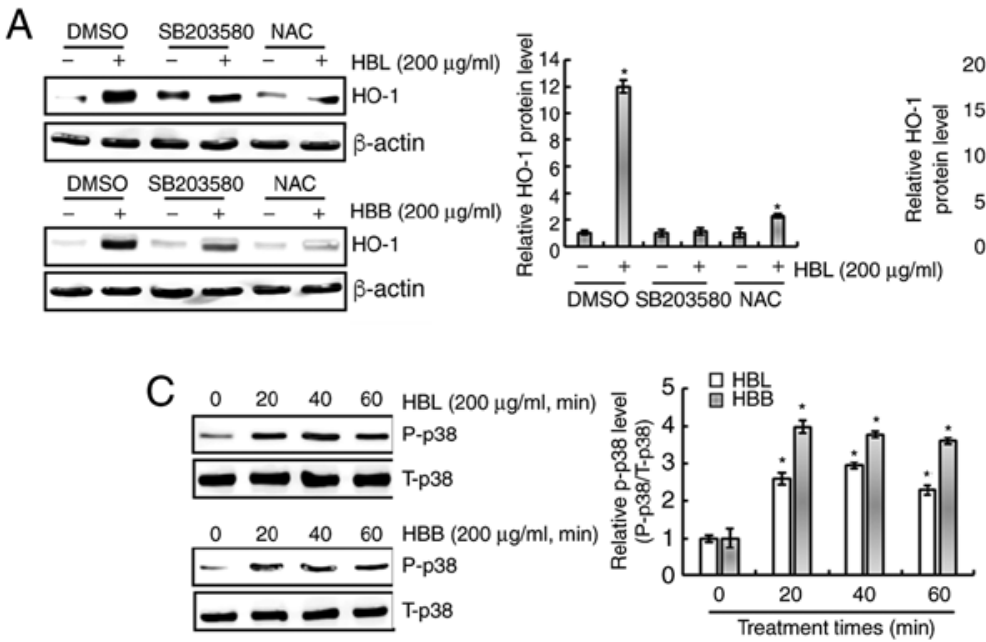

B

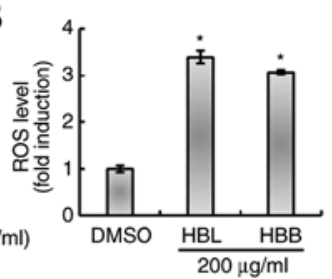

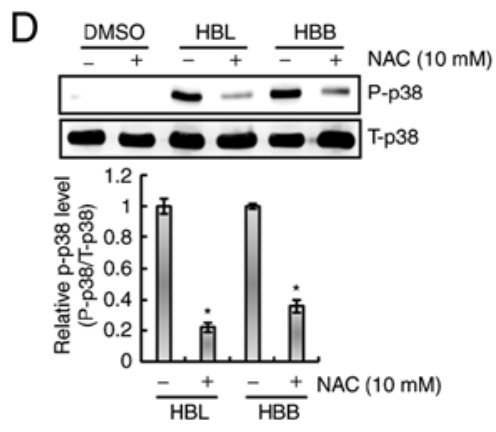

Figure 6. Effects of $\mathrm{p} 38$ and ROS on the changes in HO-1 expression mediated by HBL and HBB. (A) RAW264.7 cells were pretreated with SB203580 (20 $\mu \mathrm{M}$, p38 inhibitor) or NAC (10 mM, ROS scavenger) for $2 \mathrm{~h}$ and then co-treated with HBL (200 $\mu \mathrm{g} / \mathrm{ml})$ for $6 \mathrm{~h}$ or HBB $(200 \mu \mathrm{g} / \mathrm{ml})$ for $10 \mathrm{~h}$. (B) RAW264.7 cells were treated with $200 \mu \mathrm{g} / \mathrm{ml} \mathrm{HBL}$ or HBB for $24 \mathrm{~h}$ and then the ROS level was measured using 2',7'-dichlorofluorescein diacetate staining. (C) RAW264.7 cells were treated with $200 \mu \mathrm{g} / \mathrm{ml} \mathrm{HBL}$ and HBB for the indicated times. (D) RAW264.7 cells were pre-treated with NAC (10 mM) for $2 \mathrm{~h}$ and then co-treated with $200 \mu \mathrm{g} / \mathrm{ml} \mathrm{HBL}$ and HBB for $20 \mathrm{~min}$. The cell lysates were subjected to sodium dodecyl sulfate-polyacrylamide gel electrophoresis and western blotting was performed using antibodies against HO-1, P-p38 and p38. Actin was used as an internal control for western blot analysis. "P<0.05 vs. cells without HBL or HBB treatment. ROS, reactive oxygen species; HO-1, heme oxygenase 1; HBL, honeyberry leaf extract; HBB, honeyberry bark extract; NAC, N-acetyl-L-cysteine; P, phosphorylated; T, total; DMSO, dimethylsulfoxide.
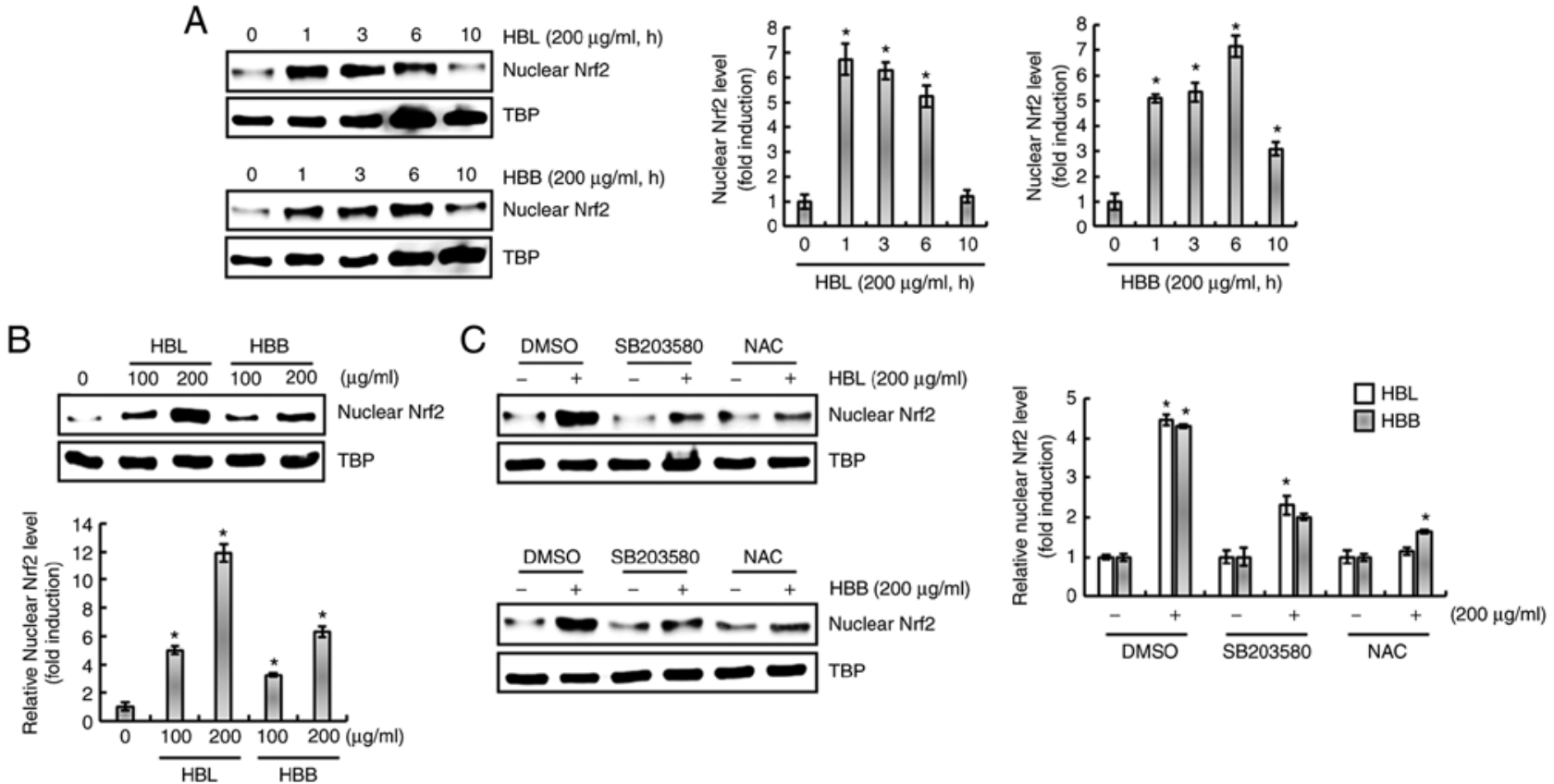

Figure 7. Effects of HBL and HBB on Nrf2 activation. (A) RAW264.7 cells were treated with $200 \mu \mathrm{g} / \mathrm{ml} \mathrm{HBL}$ and HBB for the indicated times. (B) RAW264.7 cells were treated with $200 \mu \mathrm{g} / \mathrm{ml} \mathrm{HBL}$ and HBB for $1 \mathrm{~h}$. (C) RAW264.7 cells were pre-treated with SB203580 $(20 \mu \mathrm{M})$ or NAC (10 mM) for $2 \mathrm{~h}$ and then co-treated with $200 \mu \mathrm{g} / \mathrm{ml} \mathrm{HBL}$ and HBB for $1 \mathrm{~h}$. After the treatment, nuclear protein was prepared. The cell lysates were subjected to sodium dodecyl sulfate-polyacrylamide gel electrophoresis and western blotting was performed using an antibody against Nrf2. TBP was used as the internal control for western blot analysis. ${ }^{*}<<0.05$ vs. cells without HBL or HBB treatment. HBL, honeyberry leaf extract; HBB, honeyberry bark extract; Nrf2, nuclear factor erythroid 2-related factor 2; NAC, N-acetyl-L-cysteine; TBP, TATA-box-binding protein; DMSO, dimethylsulfoxide.

have been reported in previous studies (26-30). In addition, it has been reported that ferulic acid, coumaric acid, chlorogenic acid, and caffeic acid are able to activate the Nrf2/HO-1 signaling pathway (31-34).

\section{Discussion}

Although inflammation is a beneficial response that helps to protect the body from external pathogens, it is considered that 

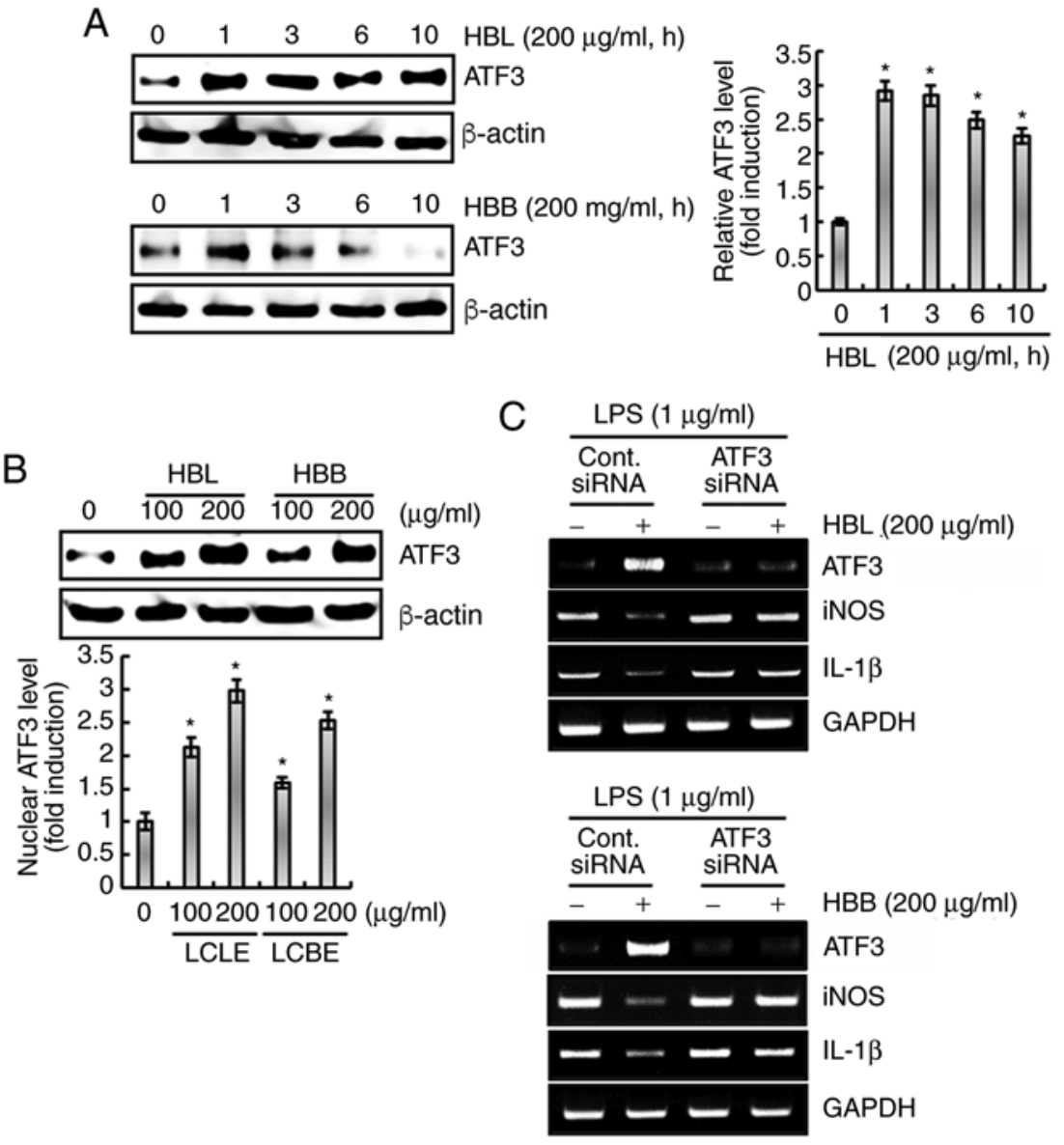
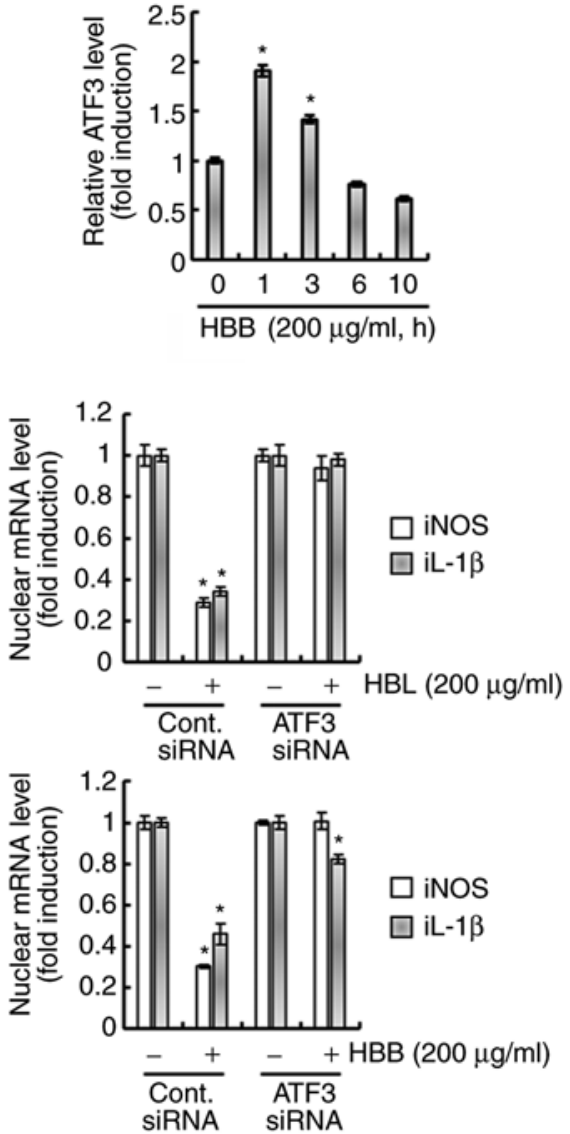

Figure 8. Effects of HBL and HBB on ATF3 expression. (A) RAW264.7 cells were treated with $200 \mu \mathrm{g} / \mathrm{ml} \mathrm{HBL}$ and HBB for the indicated times. (B) RAW264.7 cells were treated with 100 and $200 \mu \mathrm{g} / \mathrm{ml} \mathrm{HBL}$ and HBB for $1 \mathrm{~h}$. For western blot analysis, the cell lysates were subjected to sodium dodecyl sulfate-polyacrylamide gel electrophoresis and western blotting was performed using an antibody against ATF3. Actin was used as an internal control for western blot analysis. (C) RAW264.7 cells were transfected with control or ATF3 siRNA for $48 \mathrm{~h}$. After transfection, the cells were pretreated with $200 \mu \mathrm{g} / \mathrm{ml} \mathrm{HBL}$ and $\mathrm{HBB}$ for $4 \mathrm{~h}$ and then co-treated with LPS $(1 \mu \mathrm{g} / \mathrm{ml})$ for $20 \mathrm{~h}$. After the treatment, total RNA was extracted. * $\mathrm{P}<0.05 \mathrm{vs}$. cells without $\mathrm{HBL}$ and $\mathrm{HBB}$ treatment. HBL, honeyberry leaf extract; HBB, honeyberry bark extract; ATF3, activating transcription factor-3; siRNA, small interfering RNA; LPS, lipopolysaccharide; iNOS, inducible nitric oxide synthase; IL-1 $\beta$, interleukin $1 \beta$.

excessive inflammatory responses should be controlled to prevent the development of chronic inflammation-associated diseases $(1,2)$. The development of new anti-inflammatory agents is desirable due to the side effects and treatment failures associated with currently available anti-inflammatory drugs (35). There is growing evidence that various plants and plant-derived compounds have therapeutic anti-inflammatory effects with few or no side effects $(35,36)$. Thus, in the present study, the anti-inflammatory activity of HBL and HBB derived from honeyberry were evaluated and their potential molecular mechanisms of action were elucidated.

According to previous reports, HBF inhibits the production of pro-inflammatory mediators during the LPS-induced inflammatory response $(6,9)$. However, in the present study, it was observed that $\mathrm{HBF}(100 \mu \mathrm{g} / \mathrm{ml})$ did not inhibit the LPS-induced overproduction of pro-inflammatory mediators, namely NO, iNOS, and IL-1 $\beta$, whereas HBL and HBB significantly suppressed the overproduction of these mediators at the same concentration. Polyphenolic compounds are associated with lower risk of degenerative and chronic diseases than other dietary components and are known to have anti-inflammatory properties (37). The present study found that the levels of polyphenolic compounds in the extracts decreased in the order
HBL $>$ HBB $>$ HBF. This result indicates that the difference in the inhibitory activities of HBL, HBB and HBF against the production of inflammatory mediators may be associated with the levels of polyphenolic compounds they contain. We also hypothesize that the differences in the inhibitory effect of $\mathrm{HBF}$ on the production of pro-inflammatory mediators in different studies may be due to variations in the growth environment of honeyberry. This is because the secondary metabolites of plants are regulated by the environment in which the plants are grown (38).

$\mathrm{NF}-\kappa \mathrm{B}$ is an important transcription factor involved in the inflammatory response (39). Inflammatory stimuli, such as LPS, activate NF- $\kappa$ B by inducing cytosolic I $\kappa \mathrm{B}-\alpha$ degradation and the subsequent accumulation of p65 in the nucleus, which leads to the upregulation of pro-inflammatory mediators (39). Interestingly, the present study demonstrated that HBL and HBB did not inhibit the LPS-induced cytosolic degradation of I $\kappa \mathrm{B}-\alpha$ but attenuated the increase in the nuclear level of p65 protein. There is evidence that p65 phosphorylation is essential for the nuclear accumulation of p65 and transcriptional activation (40). There are various phosphorylation sites of p65, among which the phosphorylation of serine 529 has been reported to be involved in the nuclear accumulation of 
A

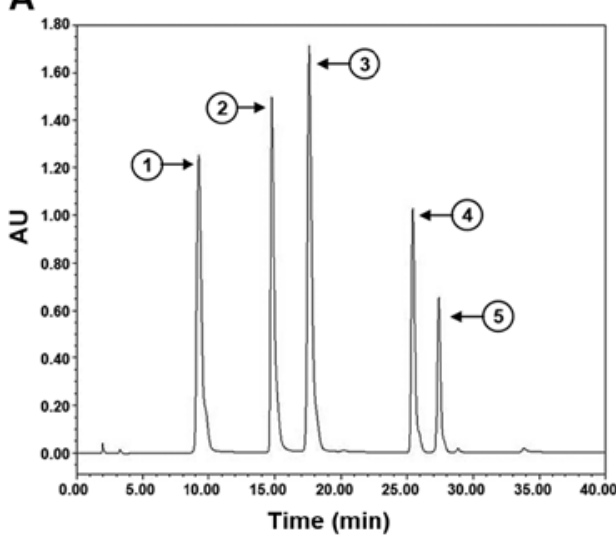

B

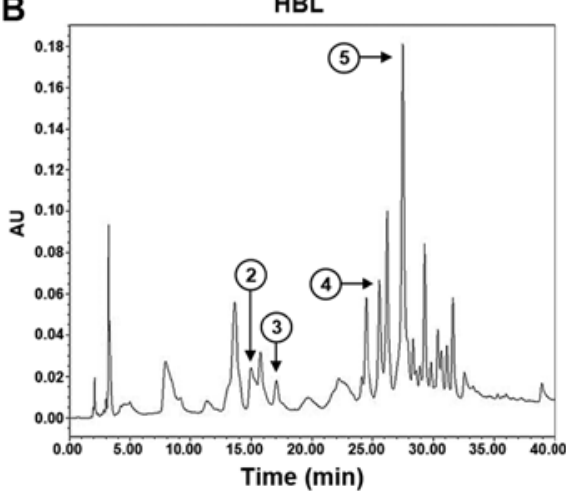

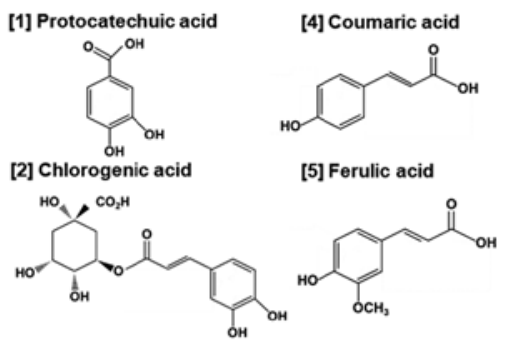

[3] Caffeic acid

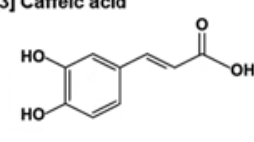

C

\begin{tabular}{c|c|c|c}
\multicolumn{4}{c}{$(\mu \mathrm{g} / g$ extracts $)$} \\
\hline Chemicals & HBL & HBB & HBF \\
\hline Protocatechic acid & - & 4.23 & 6.53 \\
\hline Chlorogenic acid & 58.66 & 21.86 & 27.23 \\
\hline Caffeic acid & 21.51 & 43.88 & - \\
Coumaric acid & 120.51 & 26.77 & 5.44 \\
Ferulic acid & 283.31 & 8.69 & 7.99 \\
\hline
\end{tabular}
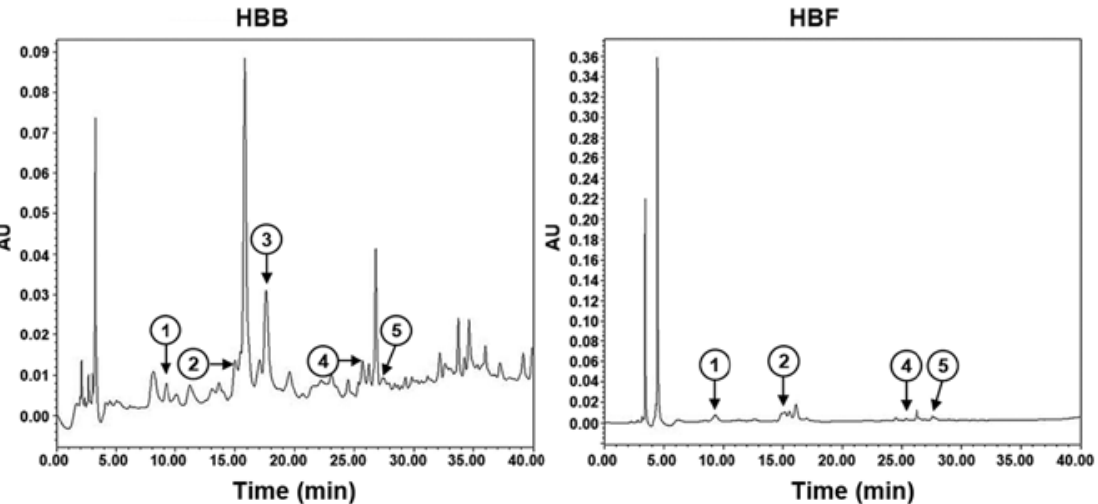

Figure 9. HPLC chromatograms of polyphenolic compounds in HBL, HBB and HBF. HPLC chromatograms of (A) the standards and (B) HBL, HBB and HBF. (C) The contents of polyphenolic compounds in HBL, HBB and HBF. HPLC, high-performance liquid chromatography; HBL, honeyberry leaf extract; $\mathrm{HBB}$, honeyberry bark extract; HBF, honeyberry flower extract.

p65 (40). Therefore, we hypothesize that the inhibitory effects of HBL and HBB on p65 nuclear accumulation are caused by the inhibition of p65 phosphorylation at serine 529. However, this hypothesis requires elucidation through further study.

MAPK is also involved in the upregulation of pro-inflammatory mediators $(41,42)$. In the present study, HBL did not inhibit the LPS-induced phosphorylation of ERK1/2 and $\mathrm{p} 38$. However, HBB suppressed LPS-induced p38 phosphorylation but not ERK1/2 phosphorylation. As p38 MAPK is considered a potential molecular target for the development of anti-inflammatory drugs, p38 inhibitors are currently being developed. The anti-inflammatory activities of these p38 inhibitors have been confirmed clinically $(41,42)$. Therefore, the data in the present study indicate that the inhibition of $\mathrm{p} 38$ activation by HBB was associated with the downregulation of pro-inflammatory mediators.

The present study also indicated that HBL and HBB upregulated the HO-1 protein expression level through the ROS/p38-dependent activation of Nrf2, and that HO-1 knockdown inhibited the downregulation of inflammatory mediators by HBL and HBB. It has previously been shown that ROS induce the expression of HO-1 through the p38-dependent activation of Nrf2 $(24,43)$, which can inhibit the inflammatory process. Therefore, Nrf2 activators are considered potential therapeutic agents for the treatment of various human diseases, including inflammatory diseases (44). Furthermore, Nrf2 activation-dependent responses are an effective means of preventing and treating inflammation, the most effective of which is the expression of HO-1 $(45,46)$. Nrf2 is a redox-sensitive transcription factor that is known to regulate the expression of antioxidant enzymes such as HO-1 (47). In the absence of stimulation, Nrf2 binds to Keap1 and is present in the cytoplasm in an inactive form. However, ROS induces the translocation of Nrf2 to the nucleus through the degradation of Keap1. Nuclear Nrf2 binds to the antioxidant response element and induces the transcription of HO-1 (48). On the basis of these previous studies $(47,48)$, we hypothesize that ROS produced by HBL and HBB may induce Nrf2 translocation into the nucleus through the degradation of Keap1, contributing the expression of HO-1. Thus, the present data may provide evidence of a link between ROS/p38/Nrf2/HO-1 signaling and the anti-inflammatory activity of HBL and HBB.

Finally, it was observed that the expression of ATF3 was increased in cells treated with HBL and HBB. It has been reported that ATF3 plays an important role in innate immunity (49) and that its expression mitigates the production of various pro-inflammatory mediators (50). In an in vivo study, ATF3 knock-out mice died sooner than wild-type mice when injected with a high dose of LPS (49). Previous studies have demonstrated that ATF3 mitigates inflammatory responses by inhibiting the overproduction of pro-inflammatory mediators (49-51). In the present study, ATF3 knockdown completely blocked the HBL- and HBB-induced downregulation of inflammatory mediators, which indicates that ATF3 may be a major mediator of the anti-inflammatory activity of HBL and HBB, although HBL and HBB can also inhibit the production 
of inflammatory mediators through various signaling pathways such as MAPK, NF-kB, and Nrf2/HO-1. It has been reported that a deficiency of ATF3 increases the production of inflammatory mediators via the inhibition of $\mathrm{Nrf} 2 / \mathrm{HO}-1$ signaling (52). Thus, the effect of the HBL- and HBB-induced expression of ATF3 on Nrf2/HO-1 signaling requires further elucidation. In addition, the mechanisms through which HBL and HBB promote the expression of ATF3 need to be investigated.

In summary, the present study demonstrated that HBL and HBB inhibited LPS-induced NF- $\kappa \mathrm{B}$ activation by blocking the nuclear accumulation of p65, increasing HO-1 expression through ROS/p38/Nrf2 activation, and increasing ATF3 expression. Furthermore, HBB inhibited LPS-induced p38 phosphorylation. The regulatory effects of $\mathrm{HBL}$ and $\mathrm{HBB}$ on these signaling pathways may be associated with their antiinflammatory activities. These findings suggest that HBL and HBB may have great potential as anti-inflammatory drugs and should be further explored for development as natural anti-inflammatory drugs. However, the study is limited as it involved only cell-based experiments. Therefore, preclinical studies using animal models are required to validate the anti-inflammatory activities of HBL and HBB prior to their development as natural anti-inflammatory drugs.

\section{Acknowledgements}

Not applicable.

\section{Funding}

This study was supported by Basic Science Research Program through the National Research Foundation of Korea (NRF) funded by the Ministry of Education (grant nos. NRF-2019R1 D1A3A03103685 and NRF-2018R1A6A1A03024862).

\section{Availability of data and materials}

All data generated or analyzed during this study are included in this published article.

\section{Authors' contributions}

JBJ directed and designed the study. MYA, HJE, HJS, NGG and GHP performed the experiments. HJE and NGG analyzed the bioactive compounds using HPLC. HJS and GHP drafted the manuscript. JBJ corrected the manuscript. All authors read and approved the final manuscript.

\section{Ethics approval and consent to participate}

Not applicable.

\section{Patient consent for publication}

Not applicable.

\section{Competing interests}

The authors declare that they have no competing interests.

\section{References}

1. Ferrero-Miliani L, Nielsen OH, Andersen PS and Girardin SE: Chronic inflammation: Importance of NOD2 and NALP3 in interleukin-1beta generation. Clin Exp Immunol 147: 227-235, 2007.

2. Xue N, Wu X, Wu L, Li L and Wang F: Antinociceptive and anti-inflammatory effect of naringenin in different nociceptive and inflammatory mice models. Life Sci 217: 148-154, 2019.

3. Sieweke MH and Allen JE: Beyond stem cells: Self-renewal of differentiated macrophages. Science 342: 1242974, 2013.

4. Medzhitov R: Inflammation 2010: New adventures of an old flame. Cell 140: 771-776, 2010.

5. Mazzoni L, Perez-Lopez P, Giampieri F, Alvarez-Suarez JM Gasparrini M, Forbes-Hernandez TY, Quiles JL, Mezzetti B and Battino M: The genetic aspects of berries: From field to health. J Sci Food Agric 96: 365-371, 2016.

6. Lee YS, Cho IJ, Kim JW, Lee SK, Ku SK and Lee HJ: Evaluation of in vitro anti-oxidant and anti-inflammatory activities of Korean and Chinese Lonicera caerulea. Nutr Res Pract 12: 486-493, 2018.

7. Svarcova I, Heinrich J and Valentova K: Berry fruits as a source of biologically active compounds: The case of Lonicera caerulea. Biomed Pap Med Fac Univ Palacky Olomouc Czech Rupub 151: 163-174, 2017.

8. Chen L, Xin X, Yuan Q, Su D and Liu W: Phytochemical properties and antioxidant capacities of various colored berries. J Sci Food Agric 94: 180-188, 2014.

9. Jin XH, Ohgami K, Shiratori K, Suzuki Y, Koyama Y, Yoshida K, Ilieva I, Tanaka T, Onoe K and Ohno S: Effects of blue honeysuckle (Lonicera caerulea L.) extract on lipopolysaccharide-induced inflammation in vitro and in vivo. Exp Eye Res 82: 860-867, 2006.

10. Zdarilova A, Rajnochova Svobodova A, Chytilova K, Simanek V and Ulrichova J: Polyphenolic fraction of Lonicera caerulea $\mathrm{L}$. fruits reduces oxidative stress and inflammatory markers induced by lipopolysaccharide in gingival fibroblasts. Food Chem Toxicol 48: 1555-1561, 2010.

11. Palikova I, Valentova K, Oborna I and Ulrichova J: Protectivity of blue honeysuckle extract against oxidative human endothelial cells and rat hepatocyte damage. J Agric Food Chem 57: 6584-6589, 2009.

12. Jurgonski A, Juskiewicz J and Zdunczyk Z: An anthocyanin-rich extract from Kamchatka honeysuckle increases enzymatic activity within the gut and ameliorates abnormal lipid and glucose metabolism in rats. Nutrition 29: 898-902, 2013.

13. Park SI, Lee YJ, Choi SH, Park SJ, Song CH and Ku SK: Therapeutic effects of blue honeysuckle on lesions of hyperthyroidism in rats. Am J Chin Med 44: 1441-1456, 2016.

14. Kim JW, Lee YS, Seol DJ, Cho IJ, Ku SK, Choi JS and Lee HJ: Anti-obesity and fatty liver-preventing activities of Lonicera caerulea in high-fat diet-fed mice. Int J Mol Med 42: 3047-3064, 2018.

15. Zhou L, Wang H, Yi J, Yang B, Li M, He D, Yang W, Zhang Y and $\mathrm{Ni} \mathrm{H}$ : Anti-tumor properties of anthocyanins from Lonicera caerulea 'Beilei' fruit on human hepatocellular carcinoma: In vitro and in vivo study. Biomed Pharmacother 104: 520-529, 2018.

16. Pace E, Jiang Y, Clemens A, Crossman T and Rupasinghe HPV: Impact of thermal degradation of cyanidin-3-O-glucoside of haskap Berry on cytotoxicity of hepatocellular carcinoma HepG2 and breast cancer MDA-MB-231 cells. Antioxidants (Basel) 7: E24, 2018.

17. Jurikova T, Rop O, Mlcek J, Sochor J, Balla S, Szekeres L, Hegedusova A, Hubalek J, Adam V and Kizek R: Phenolic profile of edible honeysuckle berries (genus Lonicera) and their biological effects. Molecules 17: 61-79, 2011.

18. Vasantha Rupasinghe HP, Arumuggam N, Amararathna M and De Silva ABKH: The potential health benefits of haskap (Lonicera caerulea L.): Role of cyaniding-3-O-glucoside. J Funct Foods 44: 24-39, 2018.

19. Rupasinghe HP, Boehm MM, Sekhon-Loodu S, Parmar I, Bors B and Jamieson AR: Anti-inflammatory activity of haskap cultivars is polyphenols-dependent. Biomolecules 5: 1079-1098, 2015.

20. Szopa A, Kokotkiewicz A, Kubica P, Banaszczak P Wojtanowska-Krośniak A, Krośniak M, Marzec-Wróblewska U, Badura A, Zagrodzki P, Bucinski A, et al: Comparative analysis of different groups of phenolic compounds in fruit and leaf extracts of Aronia sp.: A. melanocarpa, A. arbutifolia, and A. xprunifolia and their antioxidant activities. Eur Food Res Technol 243: 1645-1657, 2017. 
21. Anchalee R, Ubonrat S, Arpathsra S, Simona B and Susanna B Rapid evaluation of phenolic compounds and antioxidant activity of mulberry leaf tea during storage using electronic tongue coupled with chemometrics. J Berry Res 9: 563-574, 2019.

22. Kim HN, Park GH, Park SB, Kim JD, Eo HJ, Son HJ, Song JH and Jeong JB: Sageretia thea inhibits inflammation through suppression of NF- $\mathrm{B}$ and MAPK and activation of Nrf2/HO-1 signaling pathways in RAW264.7 cells. Am J Chin Med 47: 385-403, 2019

23. Park YS, Jung ST, Kang SG, Heo BK, Arancibia-Avila P, Toledo F, Drzewiecki J, Namiesnik J and Gorinstein S: Antioxidants and proteins in ethylene-treated kiwifruits. Food Chem 107: 640-648, 2008.

24. Jin $\mathrm{CH}$, So YK, Han SN and Kim JB: Isoegomaketone upregulates heme oxygenase-1 in RAW264.7 cells via ROS/p38 MAPK/Nrf2 pathway. Biomol Ther (Seoul) 24: 510-516, 2016.

25. Kwon JW, Kwon HK, Shin HJ, Choi YM, Anwar MA and Choi S: Activating transcription factor 3 represses inflammatory responses by binding to the p65 subunit of NF-kB. Sci Rep 5: $14470,2015$.

26. Juman S, Yasui N, Ikeda K, Ueda A, Sakanaka M, Negishi H and Miki T: Caffeic acid phenethyl ester suppresses the production of pro-inflammatory cytokines in hypertrophic adipocytes through lipopolysaccharide-stimulated macrophages. Biol Pharm Bull 35: 1941-1946, 2012

27. Kim SH, Park SY, Park YL, Myung DS, Rew JS and Joo YE: Chlorogenic acid suppresses lipopolysaccharide-induced nitric oxide and interleukin-1 $\beta$ expression by inhibiting JAK2/STAT3 activation in RAW264.7 cells. Mol Med Rep 16: 9224-9232, 2017

28. Lee M, Rho HS and Choi K: Anti-inflammatory effects of a p-coumaric acid and kojic acid derivative in LPS-stimulated RAW264.7 macrophage cells. Biotechnol Bioproc E 24: 653-657, 2019.

29. Sakai S, Ochiai H, Nakajima K and Terasawa K: Inhibitory effect of ferulic acid on macrophage inflammatory protein-2 production in a murine macrophage cell line, RAW264.7. Cytokine 9: 242-248, 1997

30. Wang Y, Zhou J, Fu S, Wang C and Zhou B: Preventive effects of protocatechuic acid on LPS-induced inflammatory response in human gingival fibroblasts via activating PPAR- $\gamma$ Inflammation 38: 1080-1084, 2015.

31. Chen JJ, Deng JS, Huang CC, Li PY, Liang YC, Chou CY and Huang GJ: p-Coumaric-acid-containing Adenostemma lavenia ameliorates acute lung injury by activating AMPK/Nrf2/HO-1 signaling and improving the anti-oxidant response. Am J Chin Med 47: 1483-1506, 2019.

32. Han D, Gu X, Gao J, Wang Z, Liu G, Barkema HW and Han B: Chlorogenic acid promotes the Nrf2/HO-1 anti-oxidative pathway by activating $\mathrm{p} 21^{\text {Waf } 1 / \text { Cipl }}$ to resist dexamethasone-induced apoptosis in osteoblastic cells. Free Radic Biol Med 137: 1-12, 2019.

33. Ma Z, Hong Q, Wang Y, Liang Q, Tan H, Xiao C, Tang X, Shao S Zhou $S$ and Gao Y: Ferulic acid induces heme oxygenase-1 via activation of ERK1/2 and Nrf2. Drug Discov Ther 5: 299-305, 2011.

34. Yang SY, Pyo MC, Nam MH and Lee KW: ERK/Nrf2 pathway activation by caffeic acid in HepG2 cells alleviates its hepatocellular damage caused by t-butylhydroperoxide-induced oxidative stress. BMC Complement Altern Med 19: 139, 2019.

35. Musialik K, Szulińska M, Hen K, Skrypnik D and Bogdański P The relation between osteoprotegerin, inflammatory processes, and atherosclerosis in patients with metabolic syndrome. Eur Rev Med Pharmacol Sci 21: 4379-4385, 2017.

36. Oguntibeju OO: Medicinal plants with anti-inflammatory activities from selected countries and regions of Africa. J Inflamm Res 11: 307-317, 2018

37. Leyva-Jiménez FJ, Lozano-Sánchez J, Cádiz-Gurrea ML, Arráez-Román D and Segura-Carretero A: Functional ingredients based on nutritional phenolics. A case study against inflammation: Lippia genus. Nutrients 11: 1646, 2019.
38. Yang L, Wen KS, Ruan X, Zhao YX, Wei F and Wang Q: Response of plant secondary metabolites to environmental factors. Molecules 23: 762, 2018.

39. Chen JW, Chen YH, Lin FY, Chen YL and Lin SJ: Ginkgo Biloba extract inhibits tumor necrosis factor-alpha-induced reactive oxygen species generation, transcription factor activation, and cell adhesion molecule expression in human aortic endothelial cells. Arterioscler Thromb Vasc Biol 23: 1559-1566, 2003.

40. Maguire O, O'Loughlin K and Minderman H: Simultaneous assessment of NF-kB/p65 phosphorylation and nuclear localization using imaging flow cytometry. J Immunol Methods 423: 3-11, 2015.

41. Kaminska B: MAPK signalling pathways as molecular targets for anti-inflammatory therapy-from molecular mechanisms to therapeutic benefits. Biochim Biophys Acta 1754: 253-262, 2005.

42. Frazier WJ, Xue J, Luce WA and Liu Y: MAPK signaling drives inflammation in LPS-stimulated cardiomyocytes: The route of crosstalk to G-protein-coupled receptors. PLoS One 7: e50071, 2012.

43. Liu X, Peyton KJ, Shebib AR, Wang H and Durante W: Compound $\mathrm{C}$ stimulates heme oxygenase-1 gene expression via the Nrf2-ARE pathway to preserve human endothelial cell survival. Biochem Pharmacol 82: 371-379, 2011.

44. Kim J, Cha YN and Surh YJ: A protective role of nuclear factor-erythroid 2-related factor-2 (Nrf2) in inflammatory disorders. Mutat Res 690: 12-23, 2010.

45. Park SY, Park DJ, Kim YH, Kim Y, Kim SG, Shon KJ, Choi YW and Lee SJ: Upregulation of heme oxygenase-1 via PI3K/Akt and Nrf-2 signaling pathways mediates the anti-inflammatory activity of schisandrin in Porphyromonas gingivalis LPS-stimulated macrophages. Immunol Lett 139: 93-101, 2011.

46. Ren J, Li L, Wang Y, Zhai J, Chen G and Hu K: Gambogic acid induces heme oxygenase-1 through Nrf2 signaling pathway and inhibits NF-kB and MAPK activation to reduce inflammation in LPS-activated RAW264.7 cells. Biomed Pharmacother 109: 555-562, 2019.

47. Lim DW, Choi HJ, Park SD, Kim H, Yu GR, Kim JE and Park WH: Activation of the Nrf2/HO-1 pathway by Amomum villosum extract suppresses LPS-induced oxidative stress in vitro and ex vivo. Evid Based Complement Alternat Med 2020: 2837853, 2020.

48. Habtemariam S: The Nrf2/HO-1 axis as targets for flavanones: Neuroprotection by pinocembrin, naringenin, and eriodictyol. Oxid Med Cell Longev 2019: 4724920, 2019.

49. Thompson MR, Xu D and Williams BR: ATF3 transcription factor and its emerging roles in immunity and cancer. J Mol Med (Berl) 87: 1053-1060, 2009.

50. Hai T, Wolford CC and Chang YS: ATF3, a hub of the cellular adaptive-response network, in the pathogenesis of diseases: Is modulation of inflammation a unifying component. Gene Expr 15: 1-11, 2010.

51. Takii R, Inouye $S$, Fujimoto $M$, Nakamura $T$, Shinkawa $T$, Prakasam R, Tan K, Hayashida N, Ichikawa H, Hai T and Nakai A: Heat shock transcription factor 1 inhibits expression of IL-6 through activating transcription factor 3. J Immunol 184: 1041-1048, 2010.

52. Rao J, Qian X, Li G, Pan X, Zhang C, Zhang F, Zhai Y, Wang X and Lu L: ATF3-mediated NRF2/HO-1 signaling regulates TLR4 innate immune responses in mouse liver ischemia/reperfusion injury. Am J Transplant 15: 76-87, 2015.

This work is licensed under a Creative Commons Attribution-NonCommercial-NoDerivatives 4.0 International (CC BY-NC-ND 4.0) License. 